\title{
Fractional Crystallization for Extracting Lithium from Cha'erhan Tail Brine
}

\author{
Weiping Liu ${ }^{1}$, Hui Xu, Xichang Shi, Xiyun Yang \\ (School of Metallurgy and Environment, Central South University, Changsha 410083, China)
}

\begin{abstract}
According to the solubility isotherms of the ternary system $\left(\mathrm{LiCl}+\mathrm{NH}_{4} \mathrm{Cl}+\mathrm{H}_{2} \mathrm{O}\right)$, fractional crystallization including primary crystallization and secondary crystallization, was designed to remove the maximum amount of $\mathrm{NH}_{4}{ }^{+}$ from Cha'erhan tail brine and raise the concentration of $\mathrm{Li}^{+}$. The particle size and surface topography during fractional crystallization were studied by XRD and SEM techniques. Then, sodium hydroxide was used for the removal of magnesium, and high purity sodium carbonate was obtained by the method of carbonation from Cha'erhan tail brine.
\end{abstract}

Keywords: fractional crystallization; extracting; lithium; brine; phase diagram; Cha'erhan

\section{Introduction}

Lithium has been used in many industries, such as the manufacturing of glass,

${ }^{1}$ Corresponding author. Tel./fax: +86 0730 88877352. E-mail address: lwpmetallurgy@ @su.edu.cn (Weiping Liu) $1 / 16$

(C) 2016. This manuscript version is made available under the Elsevier user license http://www.elsevier.com/open-access/userlicense/1.0/ 
ceramics, rubbers, pharmaceuticals, and the production of lithium-ion batteries (Vikström et al., 2013; Xu et al., 2011). As the base material of lithium salts, other industrial lithium products are downstream products of lithium carbonate (Lee et al., 2013; Liao et al., 2015). Granite-pegmatite deposits, salt lake brine, seawater, and hot springs are the primary lithium resources worldwide (Shi et al., 2011). As the requirement for lithium and its compounds continue to increase in various fields, one area of growing concern is extracting lithium from brine as lithium carbonate $(\mathrm{Xu}$ et al., 2009).

In this regard, extraction of lithium from Cha'erhan salt lake brine (Qinghai, China) is a demanding program at present and in future. The ratio of lithium to magnesium is a crucial factor in recovery of lithium from brines. The higher concentration of magnesium in the brine, the slower evaporation rate and lower lithium yield are obtained. Therefore, an economical method to separate lithium and magnesium in the Cha'erhan salt lake brine with such a low mass $\mathrm{Li}^{+} / \mathrm{Mg}^{2+}$ ratio of 0.025-0.100 is urgently needed.

The main methods of extracting lithium from low mass ratio of $\mathrm{Li}^{+} / \mathrm{Mg}^{2+}$ brine are solvent extraction, ion exchange, precipitation and calcinations-leaching (Fu and Hui, 2010; Petersková et al., 2012), etc. Solvent extraction and ion exchange methods depend on the high efficient, high reliable and environmental friendly ion exchangers and extractants, which are limited by the cost. While the precipitation and 
calcinations-leaching methods encounter the disadvantages of complex schedules and high energy consumption (Sun et al., 2007). Among the separation methods proposed is the method suggested by Xu (Xu et al., 2009, 2007), in which sulfuric acid process removed the boron, then $\mathrm{NH}_{3}$ gas and $\mathrm{NH}_{4} \mathrm{HCO}_{3}$ were added respectively in order to precipitate about $98 \%$ of $\mathrm{Mg}^{2+}$ as $\mathrm{Mg}(\mathrm{OH})_{2}$ and $\mathrm{MgCO}_{3} \cdot\left(\mathrm{NH}_{4}\right)_{2} \mathrm{CO}_{3} \cdot 4 \mathrm{H}_{2} \mathrm{O}$ respectively. Finally the tail brine was obtained, and the $\mathrm{NH}_{3}$ gas was reproduced by reacting $\mathrm{CaO}$ with $\mathrm{NH}_{4} \mathrm{Cl}$ at high temperatures thereby guaranteeing its economy. It is well known that the brine system gradually converts from $\mathrm{MgCl}_{2}+\mathrm{LiCl}+\mathrm{H}_{2} \mathrm{O}$ into $\mathrm{MgCl}_{2}+\mathrm{LiCl}+\mathrm{NH}_{4} \mathrm{Cl}+\mathrm{H}_{2} \mathrm{O}$, and finally into $\mathrm{LiCl}+\mathrm{NH}_{4} \mathrm{Cl}+\mathrm{H}_{2} \mathrm{O}$ as tail brine in the process of adding ammonia gas and ammonium bicarbonate to precipitate $\mathrm{Mg}^{2+}$. However, the details about utilization of the $\mathrm{LiCl}+\mathrm{NH}_{4} \mathrm{Cl}+\mathrm{H}_{2} \mathrm{O}$ tail brine are still unknown and are the subject of this paper, which includes $\mathrm{NH}_{4}^{+}$removal and $\mathrm{Li}^{+}$ precipitation.

Meanwhile, salt-water phase diagram is of importance for the separation of certain component from solution. The phase diagram has been used in the inorganic salt, fertilizer and soda industries (Kbir-Ariguib et al., 2001), etc. Therefore, the solubility isotherms of the ternary system $\left(\mathrm{LiCl}+\mathrm{NH}_{4} \mathrm{Cl}+\mathrm{H}_{2} \mathrm{O}\right)$ at $298.15 \mathrm{~K}$ (Ouyang et al., 2011) is used for the utilization of Cha'erhan tail brine in this study.

In this regard, based on the solubility isotherms of the ternary system $\left(\mathrm{LiCl}+\mathrm{NH}_{4} \mathrm{Cl}+\mathrm{H}_{2} \mathrm{O}\right)$, fractional crystallization including primary and secondary 
crystallizations has been designed and conducted at $298.15 \mathrm{~K}$ to remove the component of $\mathrm{NH}_{4}{ }^{+}$and raise the concentration of $\mathrm{Li}^{+}$. Meanwhile, the principles of particle size and surface topography during fractional crystallization were studied. Finally, $\mathrm{NaOH}$ is chosen to raise the mass ratio of $\mathrm{Li}^{+} / \mathrm{Mg}^{2+}$, and $\mathrm{Na}_{2} \mathrm{CO}_{3}$ is used as precipitant for the final product of lithium carbonate.

\section{Material and methods}

Sodium and potassium from Cha'erhan salt lake brine were removed by solar ponds production at first. The composition of brine after the removal of sodium and potassium is listed as: $\mathrm{B}_{2} \mathrm{O}_{3} 2 \sim 4 \%, \mathrm{Mg}^{2+} 80 \sim 120 \mathrm{~g} / 1, \mathrm{Li}^{+} 3 \sim 8 \mathrm{~g} / \mathrm{l}$ (Xu et al., 2007). The boron was removed by sulfuric acid, and magnesium was removed by adding $\mathrm{NH}_{3}$ gas and $\mathrm{NH}_{4} \mathrm{HCO}_{3}$ respectively. The main chemical equations are below (Xu et al., 2009).

$$
\begin{gathered}
\mathrm{MgCl}_{2}+2 \mathrm{NH}_{3} \uparrow+2 \mathrm{H}_{2} \mathrm{O} \rightarrow \mathrm{Mg}(\mathrm{OH})_{2} \downarrow+2 \mathrm{NH}_{4} \mathrm{Cl} \\
\mathrm{MgCl}_{2}+2 \mathrm{NH}_{4} \mathrm{HCO}_{3}+2 \mathrm{NH}_{3} \uparrow+4 \mathrm{H}_{2} \mathrm{O} \rightarrow \mathrm{MgCO}_{3} \cdot\left(\mathrm{NH}_{4}\right)_{2} \mathrm{CO}_{3} \cdot 4 \mathrm{H}_{2} \mathrm{O} \downarrow+2 \mathrm{NH}_{4} \mathrm{Cl}
\end{gathered}
$$

After the removal of sodium, potassium, boron and magnesium, the main composition of the Cha'erhan tail brine is listed as $\mathrm{Li}^{+} 4.5 \mathrm{~g} / \mathrm{l}, \mathrm{Mg}^{2+} 1.9 \mathrm{~g} / \mathrm{l}, \mathrm{NH}_{4}{ }^{+} 81.8$ $\mathrm{g} / \mathrm{l}, \mathrm{Cl}^{-} 189.3 \mathrm{~g} / \mathrm{l}$. Thus the Cha'erhan tail brine can be treated as $\mathrm{NH}_{4} \mathrm{Cl}+\mathrm{LiCl}+\mathrm{H}_{2} \mathrm{O}$ ternary system due to small amount of $\mathrm{Mg}^{2+}$ ion. According to the phase diagram of the $\mathrm{NH}_{4} \mathrm{Cl}+\mathrm{LiCl}+\mathrm{H}_{2} \mathrm{O}$ system at $298.15 \mathrm{~K}$ in Fig. 1 (Ouyang et al., 2011), fractional crystallization including primary crystallization and secondary crystallization in the $\mathrm{NH}_{4} \mathrm{Cl}$ crystallization branch of the phase diagram, was designed to remove the 
component of $\mathrm{NH}_{4}{ }^{+}$and raise the concentration of $\mathrm{Li}^{+}$.

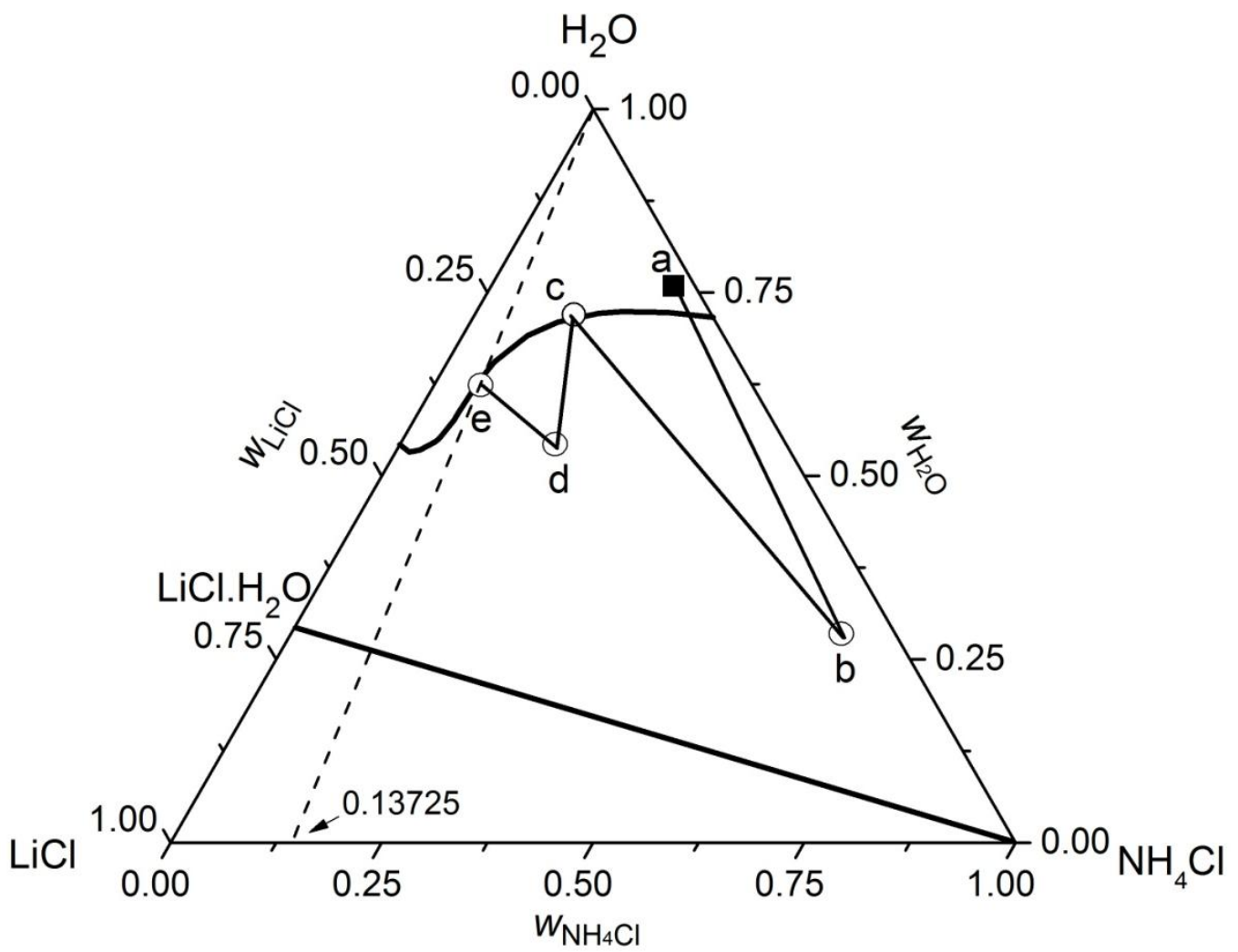

Fig. 1. Phase diagram of the system $\mathrm{NH}_{4} \mathrm{Cl}+\mathrm{LiCl}+\mathrm{H}_{2} \mathrm{O}$ at $298.15 \mathrm{~K}$ (Ouyang et al., 2011).

The Cha'erhan tail brine was designated as point "a (a)" in Fig. 1. During the primary crystallization, $65 \mathrm{wt} \%$ of brine was evaporated and the brine can be concentrated to point "b" $\left[w_{\mathrm{NH}_{4} \mathrm{Cl}} /\left(w_{\mathrm{NH}_{4} \mathrm{Cl}}+w_{\mathrm{LiCl}}\right)=0.900\right]$ from point "a", then $\mathrm{NH}_{4} \mathrm{Cl}$ was crystallized and the brine reached point "c" $\left[w_{\mathrm{NH}_{4} \mathrm{Cl}} /\left(w_{\mathrm{NH}_{4} \mathrm{Cl}}+w_{\mathrm{LiCl}}\right)=0.425\right]$. After that, secondary crystallization followed. In order to avoid the formation of $\mathrm{LiCl} \cdot \mathrm{H}_{2} \mathrm{O}$ along with $\mathrm{NH}_{4} \mathrm{Cl}$, the salt composition in the brine should be controlled to $w_{\mathrm{NH}_{4} \mathrm{Cl}} /\left(w_{\mathrm{NH}_{4} \mathrm{Cl}}+w_{\mathrm{LiCl}}\right)>0.13725$ at $298.15 \mathrm{~K}$ (Ouyang et al., 2011). Therefore, 36 wt $\%$ of brine was evaporated and the brine reached point "d" $\left[w_{\mathrm{NH}_{4} \mathrm{Cl}} /\left(w_{\mathrm{NH}_{4} \mathrm{Cl}}+w_{\mathrm{LiCl}}\right)\right.$ 
$=0.425]$, then point "e" $\left[w_{\mathrm{NH}_{4} \mathrm{Cl}} /\left(w_{\mathrm{NH}_{4} \mathrm{Cl}}+w_{\mathrm{LiCl}}\right)=0.13725\right]$ after the crystallization of $\mathrm{NH}_{4} \mathrm{Cl}$. Thus, it can be seen that $w_{\mathrm{NH}_{4} \mathrm{Cl}} /\left(w_{\mathrm{NH}_{4} \mathrm{Cl}}+w_{\mathrm{LiCl}}\right)$ can theoretically decrease from 0.900 to 0.13725 through the fractional crystallization process.

Each evaporation experiment consumed $100 \mathrm{ml}$ brine. The experiment was conducted in a glass evaporating dish, which was heated by a resistance furnace. An exhaust fan was placed to supply a discontinuous air draft, which accelerated the rate of evaporation. Newly samples were obtained from different evaporation capacities, and then were chemically analyzed. After the filtration, the solid and liquid phases were separated, and the relevant parameters were determined. Liquids and solids collected from primary crystallization are designated as L1, L2, L3, L4, L5 and S1, S2, S3, S4, S5 respectively. Then, L5 was chosen as raw material for the secondary crystallization. The liquid and solid collected from secondary crystallization were named as L6 and S6 separately.

The concentration of $\mathrm{NH}_{4}^{+}$was determined by the method of distillation combined with aicd-base titration (Haitang et al., 2012). The concentration of $\mathrm{Mg}^{2+}$ was determined by titrating the $\mathrm{Mg}^{2+}$ with EDTA. The total concentration of $\mathrm{MgCl}_{2}$, $\mathrm{LiCl}$, and $\mathrm{NH}_{4} \mathrm{Cl}$ in the system was determined by precipitating $\mathrm{Cl}^{-}$ions with $\mathrm{AgNO}_{3}$ (Kolthoff et al., 1969). The difference between the total amount of $\mathrm{Cl}^{-}$and the sum of $\mathrm{NH}_{4}{ }^{+}$and $\mathrm{Mg}^{2+}$ gives the concentration of $\mathrm{Li}^{+}$. Evaporation capacity means the volume of water which evaporated in the evaporating experiment. 


\section{Results and Discussions}

\subsection{Fractional crystallizations}

Based on the solubility isotherms of the $\left(\mathrm{LiCl}+\mathrm{NH}_{4} \mathrm{Cl}+\mathrm{H}_{2} \mathrm{O}\right)$ ternary system and the "level rule", $70 \mathrm{~g}$ water from $100 \mathrm{ml}$ brine (L1) was evaporated during the primary crystallization to reach point "b", and then $40 \mathrm{~g}$ water from $100 \mathrm{ml}$ brine (L5) in the secondary crystallization to reach point "d". In order to have a preliminary evaluation of the filtration performance of the crystallized solids, several samples were collected at different evaporation capacity during the fractional crystallization in order to observe the principles of particle size and surface topography.

\subsubsection{Primary crystallization}

The samples were collected at different evaporation capacities of 30, 40, 50, 60, $70 \mathrm{~g}$ water per $100 \mathrm{ml}$ brine. The chemical composition of liquids and solids are shown in Fig. 2 and 3.

As shown in Fig. 2, it is obvious that the concentration of $\mathrm{Li}^{+}$increases from 4.5 to $30.50 \mathrm{~g} / \mathrm{l}$ as the increasing of the evaporation capacity. However, the mass ratio of $\mathrm{Li}^{+} / \mathrm{Mg}^{2+}$ fluctuates around 2, further magnesium removal is needed to increase the mass ratio of $\mathrm{Li}^{+} / \mathrm{Mg}^{2+}$. Meanwhile, the concentration of $\mathrm{NH}_{4}^{+}$decreases from 
$85.66 \mathrm{~g} / \mathrm{l}$ to $57.30 \mathrm{~g} / \mathrm{l}$ with the evaporation capacity of $60 \mathrm{~g}$, then few variables is observed while the evaporation capacity increases to $70 \mathrm{~g}$. The results above indicate that the primary crystallization has removed the theoretical maximum amount of $\mathrm{NH}_{4}{ }^{+}$from the tail brine according the phase diagram of $\mathrm{LiCl}+\mathrm{NH}_{4} \mathrm{Cl}+\mathrm{H}_{2} \mathrm{O}$. In order to further remove $\mathrm{NH}_{4}{ }^{+}$, secondary crystallization is needed.

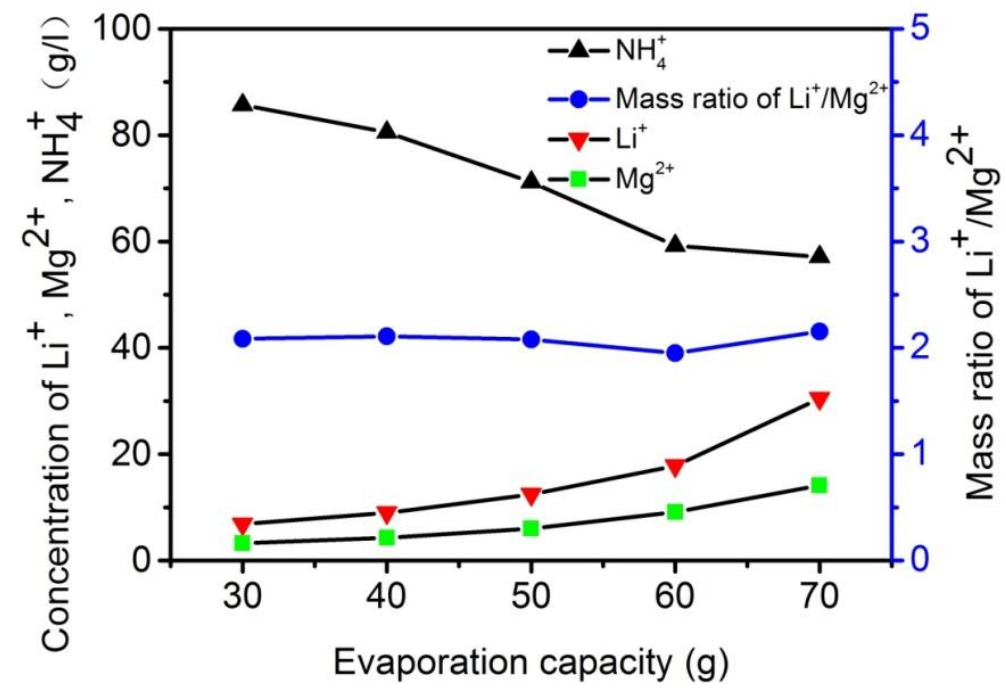

Fig. 2. Relationship between concentration of $\mathrm{Li}^{+}, \mathrm{Mg}^{2+}, \mathrm{NH}_{4}{ }^{+}$, mass ratio of $\mathrm{Li}^{+} / \mathrm{Mg}^{2+}$ and evaporation capacity.

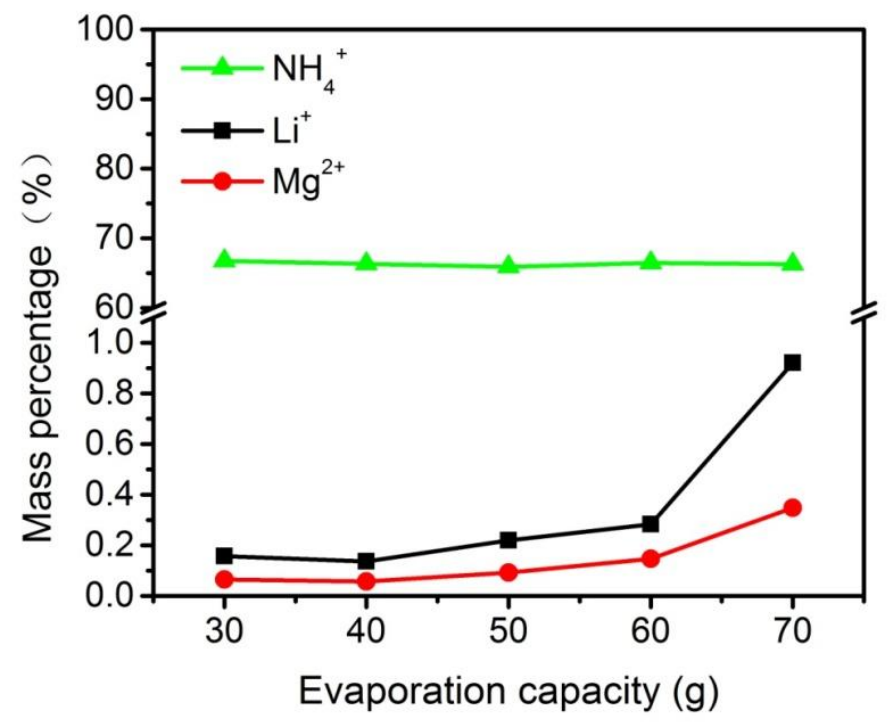

Fig. 3. Relationship between mass percent of $\mathrm{Li}^{+}, \mathrm{Mg}^{2+}, \mathrm{NH}_{4}{ }^{+}$and evaporation capacity. 
The mass percentages of $\mathrm{Li}^{+}$and $\mathrm{Mg}^{2+}$ in solids increase steadily, with the rate of less than $1 \%$ and $0.5 \%$ separately as shown in Fig. 3. The mass percentage of $\mathrm{NH}_{4}{ }^{+}$ during primary crystallization is around $66.3 \%$, which is the theoretical mass percentage of $\mathrm{NH}_{4}{ }^{+} / \mathrm{NH}_{4} \mathrm{Cl}$. Together with the XRD results of "S1", "S3" and "S5" as shown in Fig. 4, these results confirm that $\mathrm{NH}_{4} \mathrm{Cl}$ is the only solid phase and no other phases existed. The results above are consistent with the solubility isotherms of the ternary system $\left(\mathrm{LiCl}+\mathrm{NH}_{4} \mathrm{Cl}+\mathrm{H}_{2} \mathrm{O}\right)$, which indicates that the route of fractional crystallization is in the $\mathrm{NH}_{4} \mathrm{Cl}$ crystallization branch.

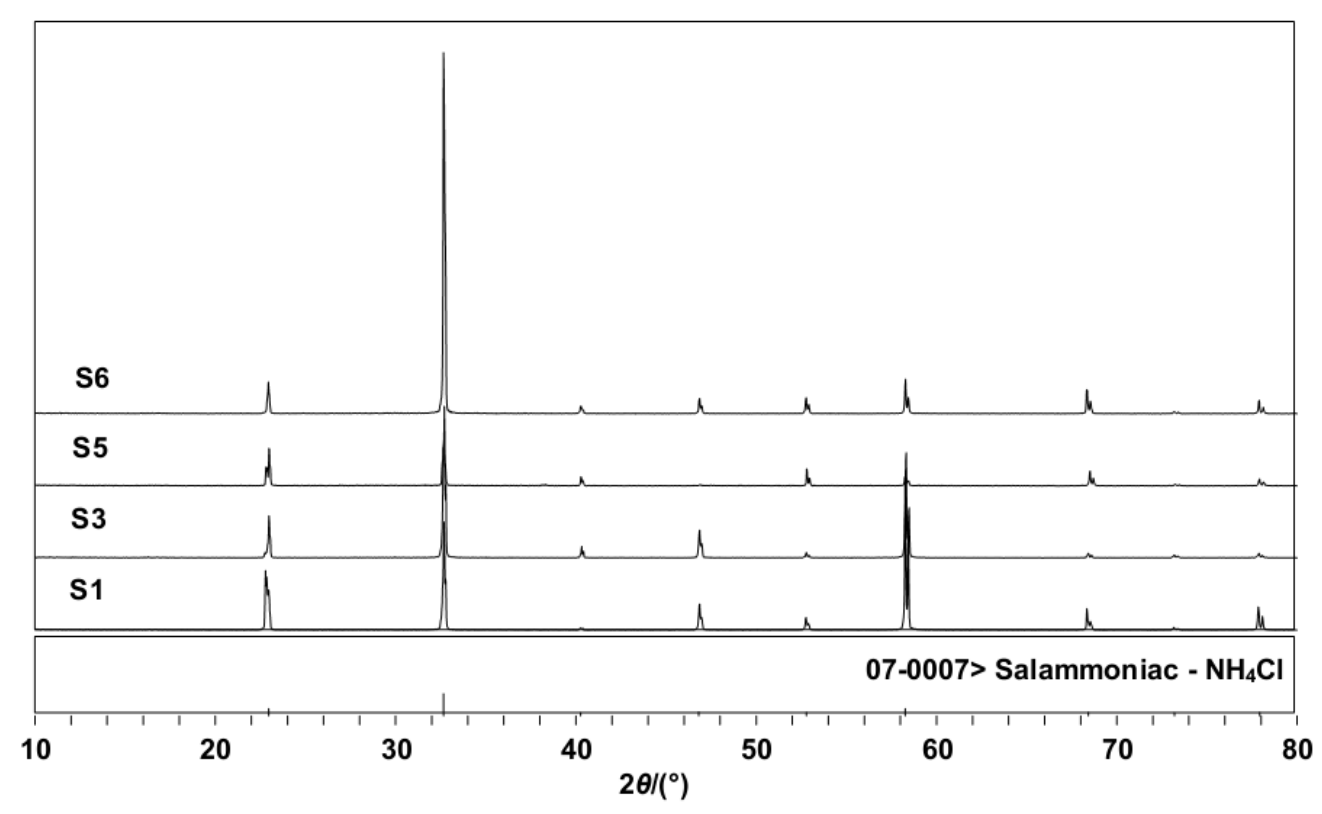

Fig. 4 XRD results.

\subsubsection{Secondary crystallization}

It is noted that the secondary crystallization increased the concentration of $\mathrm{Li}^{+}$up to the maximal concentration of $38.82 \mathrm{~g} / \mathrm{l}$, avoiding the formation of $\mathrm{LiCl} \cdot \mathrm{H}_{2} \mathrm{O}$ at the 
same time as "S6" confirmed in Fig. 4. The concentration of $\mathrm{Mg}^{2+}$ also increased to $18.83 \mathrm{~g} / \mathrm{l}$, magnesium removal procedure is thus followed to increase the mass ratio of $\mathrm{Li}^{+} / \mathrm{Mg}^{2+}$
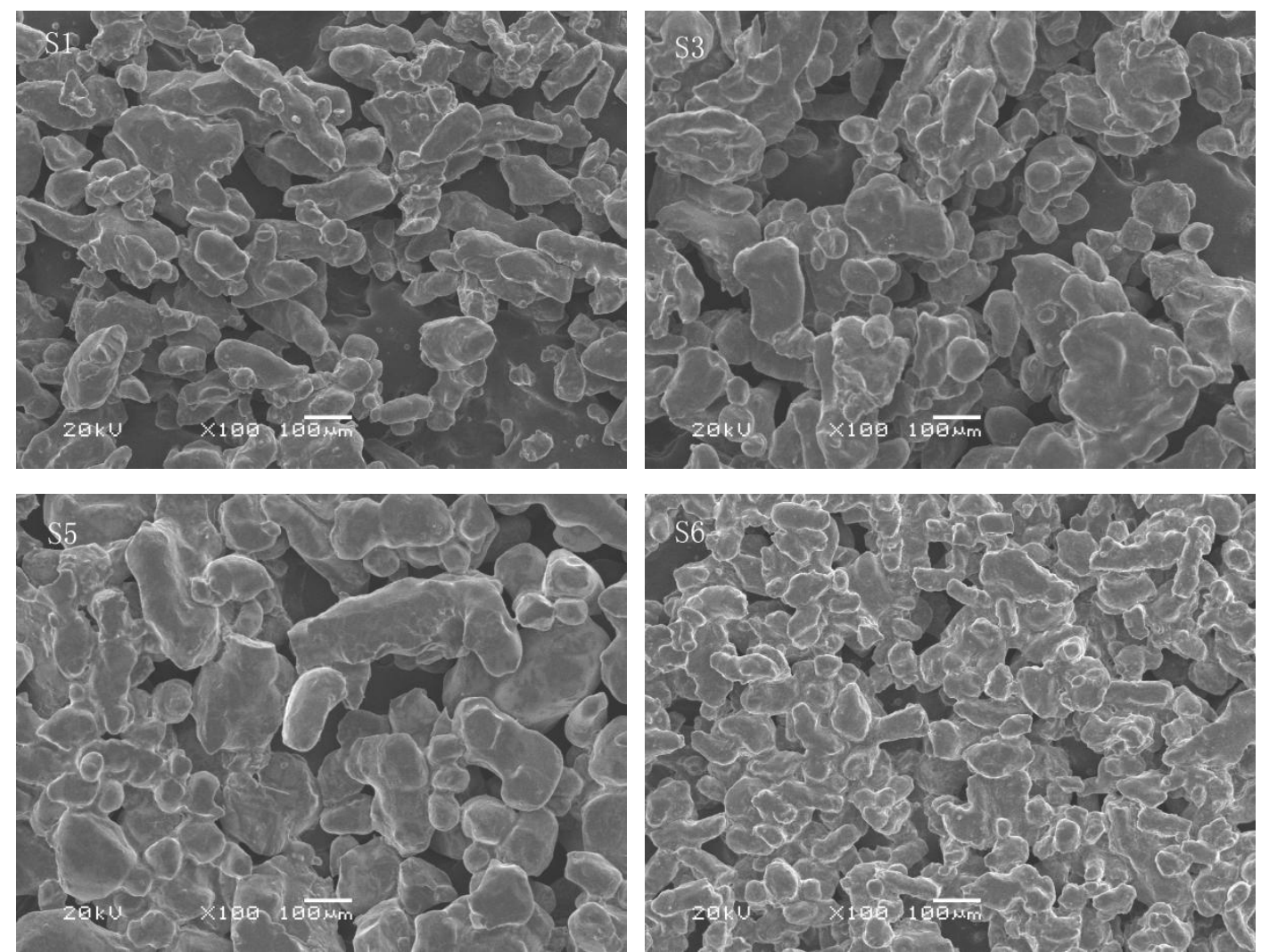

Fig. 5 SEM patterns of the solids.

Fig. 5 shows that the particle size of sheet-shape $\mathrm{NH}_{4} \mathrm{Cl}$ increases with the evaporation capacity during primary crystallization, and its particle size is in the range of $50-500 \mu \mathrm{m}$. During the secondary crystallization, the particle size is sharply decreased to $50-150 \mu \mathrm{m}$, which is caused by the higher concentration of the tail brine in secondary crystallization comparing with the case in primary crystallization. 
Based on the ammonia chloride particle size of larger than $50 \mu \mathrm{m}$, it is expected that low moisture content, high filtration speed of ammonia chloride can be achieved (Xu et al., 2005). The particle size and surface tomography is associated with the filtration performance. Further systematic examinations concerning about the surface tomography, particle size and filtration performance during the fractional crystallization are necessary, which parameters include evaporation intensity, temperature, and the evaporation method, etc.

\subsection{Removal of $\mathrm{Mg}^{2+}$}

The main reagents for the precipitation of magnesium are ammonia gas, calcium hydroxide and sodium hydroxide (Xu et al., 2009). Considering the features of high purity and strong alkaline, sodium hydroxide is chosen to remove magnesium. The reactions are shown as equations (3-4). The optimum factors are followed: sodium hydroxide excessive factor $1.5 ; 25^{\circ} \mathrm{C}$; reaction time $15 \mathrm{~min}$; aging time $45 \mathrm{~min} ; \mathrm{NaCl}$ addition (50\% of this reaction output); $\mathrm{Mg}(\mathrm{OH})_{2}$ addition $(50 \%$ of this reaction output).

$$
\begin{gathered}
\mathrm{MgCl}_{2}+2 \mathrm{NaOH} \rightarrow \mathrm{Mg}(\mathrm{OH})_{2} \downarrow+2 \mathrm{NaCl} \\
\mathrm{NH}_{4} \mathrm{Cl}+\mathrm{NaOH} \rightarrow \mathrm{NH}_{3} \cdot \mathrm{H}_{2} \mathrm{O}+\mathrm{NaCl}
\end{gathered}
$$


$\mathrm{Mg}^{2+}$ precipitated as $\mathrm{Mg}(\mathrm{OH})_{2}$ with the purity of $99.50 \%$ and $\mathrm{Li}^{+}$remained in the solution due to the huge difference between solubility of $\mathrm{Mg}(\mathrm{OH})_{2}(0.0009 \mathrm{~g} / 100 \mathrm{~g}$; $\left.18^{\circ} \mathrm{C}\right)$ and $\mathrm{LiOH} \cdot \mathrm{H}_{2} \mathrm{O}\left(12.8 \mathrm{~g} / 100 \mathrm{~g} ; 20^{\circ} \mathrm{C}\right)$ (Yao et al., 1983). The concentration of $\mathrm{Li}^{+}$ raised a little from 38.82 to $39.52 \mathrm{~g} / \mathrm{l}$, and the mass ratio of $\mathrm{Li}^{+} / \mathrm{Mg}^{2+}$ increased from 2.06 to 34.07 dramatically. It should be noted that $\mathrm{NH}_{4} \mathrm{Cl}$ and $\mathrm{NH}_{3} \cdot \mathrm{H}_{2} \mathrm{O}$ coexisted and formed a buffer system, especially at the end of the magnesium removal process as shown in equation (4). Therefore, the $\mathrm{pH}$ value of the solution is in a stable area of less than 12, which is the preferred $\mathrm{pH}$ for the precipitation of $\mathrm{Mg}^{2+}$ (Xu et al., 2009). Thus the removal efficiency of $\mathrm{Mg}^{2+}$ is limited to $90.76 \%$.

\subsection{Precipitation of $\mathrm{Li}^{+}$by $\mathrm{Na}_{2} \mathrm{CO}_{3}$}

Lithium carbonate is usually prepared by adding sodium carbonate into lithium chloride solution. Suitable factors are below: sodium carbonate excessive factor 1.5; $90{ }^{\circ} \mathrm{C}$; reaction time $2 \mathrm{~h} ; \mathrm{Li}_{2} \mathrm{CO}_{3}$ addition $(50 \%$ of the reaction output); $250 \mathrm{r} / \mathrm{min}$.

$$
2 \mathrm{LiCl}+\mathrm{Na}_{2} \mathrm{CO}_{3} \rightarrow \mathrm{Li}_{2} \mathrm{CO}_{3} \downarrow+2 \mathrm{NaCl}
$$

The element analysis showed that the precipitation efficiency of $\mathrm{Li}^{+}$reaches $96.10 \%$, and only $1.10 \mathrm{~g} / \mathrm{l}$ of $\mathrm{Li}^{+}$was left in the tail brine. However, the purity of lithium carbonate only reached $98.20 \%$ due to the limited removal efficiency of $\mathrm{Mg}^{2+}$. Following purification of $\mathrm{Li}_{2} \mathrm{CO}_{3}$ is needed. The slurry was then leached with carbon 
dioxide gas and the resulting bicarbonate solution was heated to prepare lithium carbonate as shown in equations (6-7) (Jandová et al., 2010). According to the ICP and AAS measurements results in Table 1, the purity of lithium carbonate reached $99.70 \%$, which is comparable with the lithium carbonate of $99.55 \%$ prepared from Uyuni salar brine, Bolivia (An et al., 2012). The XRD measurement confirms that lithium carbonate is the main phase and no other phases coexisted.

$$
\begin{aligned}
& \mathrm{Li}_{2} \mathrm{CO}_{3}+\mathrm{CO}_{2}+\mathrm{H}_{2} \mathrm{O} \rightarrow 2 \mathrm{LiHCO}_{3} \\
& 2 \mathrm{LiHCO}_{3} \rightarrow \mathrm{Li}_{2} \mathrm{CO}_{3}+\mathrm{CO}_{2}+\mathrm{H}_{2} \mathrm{O}
\end{aligned}
$$

Table 1. Purity of $\mathrm{Li}_{2} \mathrm{CO}_{3}$ and content of major impurities.

\begin{tabular}{ccccccc}
\hline \multirow{2}{*}{ Purity of } & \multicolumn{7}{c}{ Content of major impurities, \% } \\
\cline { 2 - 7 } $\mathrm{Li}_{2} \mathrm{CO}_{3}, \%$ & $\mathrm{Mg}$ & $\mathrm{Na}$ & $\mathrm{K}$ & $\mathrm{Al}$ & $\mathrm{Si}$ & $\mathrm{P}$ \\
\hline 99.70 & 0.04 & 0.04 & 0.038 & 0.0016 & 0.025 & 0.04 \\
\hline
\end{tabular}

However, the origins of the impurities in lithium carbonate, the distribution and the specific existing forms of the impurities associated with the fractional crystallization, magnesium removal and lithium carbonation procedures are still unknown. In order to have a better impurity control in the production of lithium carbonate, a systematic examination of the impurities is needed. 


\section{Conclusions}

Based on the solubility isotherms of the ternary system $\left(\mathrm{LiCl}+\mathrm{NH}_{4} \mathrm{Cl}+\mathrm{H}_{2} \mathrm{O}\right)$, fractional crystallization including primary crystallization and secondary crystallization was designed to remove the maximum amount of $\mathrm{NH}_{4}{ }^{+}$. Then magnesium removal and lithium precipitation procedures were followed to obtain the high purity lithium carbonate. The preliminary research indicates that the method discussed above is a promising way for the utilization of Cha'erhan salt lake tail brine. The pilot test is needed.

Conclusions at this time include the following points:

1. The fractional crystallization including primary crystallization and secondary crystallization raised the $\mathrm{Li}^{+}$concentration of Cha'erhan tail brine from $4.5 \mathrm{~g} / \mathrm{l}$ up to the maximum concentration of $38.82 \mathrm{~g} / \mathrm{l}$, and the maximum amount of $\mathrm{NH}_{4}{ }^{+}$was removed at the same time.

2. The particle size of the sheet-shape $\mathrm{NH}_{4} \mathrm{Cl}$ is in the range of $50-500 \mu \mathrm{m}$ for the primary crystallization, and $50-150 \mu \mathrm{m}$ for the secondary crystallization.

3. The mass ratio of $\mathrm{Li}^{+} / \mathrm{Mg}^{2+}$ increases dramatically from 2.06 to 34.07 after the removal of magnesium, and high purity of $99.70 \%$ lithium carbonate is obtained finally. 
The financial assistance of National Science Foundation (51574286) is gratefully acknowledged.

\section{References}

An, J.W., Kang, D.J., Tran, K.T., Kim, M.J., Lim, T., Tran, T., 2012. Recovery of lithium from Uyuni salar brine. Hydrometallurgy 117-118, 64-70. doi:10.1016/j.hydromet.2012.02.008

Fu, Y., Hui, Z., 2010. Research situation of separating magnesium and lithium from high $\mathrm{Mg} / \mathrm{Li}$ ratio salt lake brine. Multipurp. Util. Miner. Resour. 2, 10.

Haitang, Y., Dewen, Z., Yan, Y., 2012. Determination of $\mathrm{NH}_{4}^{+}$and $\mathrm{NO}_{3}^{-}$in salt-water system by distillation-acid-base titration. Metall. Anal. 32, 23-28.

Jandová, J., Dvořák, P., Hong, N.V., 2010. Processing of zinnwaldite waste to obtain $\mathrm{Li}_{2} \mathrm{CO}_{3}$. Hydrometallurgy $103,12-18$.

Kbir-Ariguib, N., Chehimi, D.B.H., Zayani, L., 2001. Treatment of Tunisian salt lakes using solubility phase diagrams. Pure Appl. Chem. 73, 761-770.

Kolthoff, I.M., Sandell, E.B., Meehan, E.J., Bruckenstein, S., 1969. Quantitative chemical analysis. Macmillan London.

Lee, J., Yu, S.H., Kim, C., Sung, Y.E., Yoon, J., 2013. Highly selective lithium recovery from brine using a lambda- $\mathrm{MnO}_{2}$-Ag battery. Phys Chem Chem Phys 15, 7690-7695. doi:10.1039/c3cp50919b

Liao, H., Xu, H., Li, G., Cheng, J., Liu, W., 2015. Study on preparation of carbonate lithium from magnesium hydroxide waste of lithium extraction process by nanofiltration. Mater. Rev. 29, 90-94. 
Ouyang, H., Zeng, D., Zhou, H., Han, H., Yao, Y., 2011. Solubility of the ternary system $\mathrm{LiCl}+\mathrm{NH}_{4} \mathrm{Cl}+\mathrm{H}_{2} \mathrm{O}$. J. Chem. Eng. Data 56, 1096-1104. doi:10.1021/je101056t

Petersková, M., Valderrama, C., Gibert, O., Cortina, J.L., 2012. Extraction of valuable metal ions (Cs, Rb, Li, U) from reverse osmosis concentrate using selective sorbents. Desalination 286, 316-323. doi:10.1016/j.desal.2011.11.042

Shi, X., Zhou, D., Zhang, Z., Yu, L., Xu, H., Chen, B., Yang, X., 2011. Synthesis and properties of $\operatorname{Li}_{1.6} \mathrm{Mn}_{1.6} \mathrm{O}_{4}$ and its adsorption application. Hydrometallurgy 110,99-106. doi:10.1016/j.hydromet.2011.09.004

Sun, X., Chen, B., Xu, H., Shi, X., 2007. Extraction of lithium from bittern. J. Cent. South Univ. 38, 262-266.

Vikström, H., Davidsson, S., Höök, M., 2013. Lithium availability and future production outlooks. Appl. Energy $110,252-266$.

Xu, H., Li, X., Chen, B., Shi, X., Liu, R., Ma, Y., Deng, X., 2005. Method of preparing high purity magnesiun sand using salt lake bischofite as raw material.CN1618998 A.

Xu, H., Liu, W., Su, Y., Shi, X., Yang, X., 2011. Study on synthesis of $\mathrm{Li}_{1-\mathrm{x}} \mathrm{Cr}_{\mathrm{X}} \mathrm{FePO}_{4}$ by microwave processing. Mater. Rev. 25, 150-152.

Xu, H., Mao, X., Li, Z., Shi, X., Pang, Q., Chen, B., Yang, X., Wang, H., 2007. Method for combined extracting boron, magnesium and lithium from salt lake bittern.CN100528753 C.

Xu, H., Xu, L., Chen, B., Shi, X., Yang, X., 2009. Separating technique for magnesium and lithium from high $\mathrm{Mg} / \mathrm{Li}$ ratio salt lake brine. J. Cent. South Univ. 40, 36-40.

Yao, Y., Xie, T., Gao, Y., 1983. Handbook of physical chemistry. Shanghai scientific \& technical publishers. 